\title{
JENIS TINDAK TUTUR YANG MENGIKUTI INTERJEKSI PANGGILAN DALAM BAHASA JEPANG
}

\author{
Maharani Patria Ratna \\ Program Studi Bahasa dan Sastra Jepang, Universitas Diponegoro, \\ Jl. Prof. Soedarto, SH, Kampus Undip Tembalang, Semarang, Indonesia 50275
}

\begin{abstract}
Abstrak
Dalam bertutur, ada kalanya suatu interjeksi panggilan dapat diikuti oleh lebih dari satu jenis tindak tutur. Penelitian ini membahas mengenai interjeksi panggilan apa saja yang digunakan penutur lakilaki dalam film Brother beat. Selain itu penelitian ini juga membahas mengenai jenis tindak tutur apa saja yang dapat mengikuti interjeksi panggilan dalam sebuah tuturan. Data dalam penelitian ini adalah tuturan yang mengandung interjeksi panggilan yang dituturkan oleh penutur pria dalam film Brother Beat. Metode yang digunakan adalah metode deskriptif kualitatif. Untuk mendapatkan data, digunakan metode simak teknik sadap catat. Hasil yang didapat dalam penelitian ini adalah, interjeksi panggilan, anosa, oi, anona, nee, you, dan ano, adalah interjeksi yang sering dipakai penutur laki-laki untuk memanggil petutur. Setelah interjeksi panggilan tersebut, tindak tutur direktif dan tindak tutur asertif adalah tindak tutur yang muncul mengikuti interjeksi panggilan. Interjeksi anosa, oi, anona, dan ano merupakan interjeksi yang dapat diikuti oleh tindak tutur direktif dan tindak tutur asertif. Di sisi lain interjeksi panggilan nee, hanya diikuti oleh tindak tutur direktif, sedangkan interjeksi you diikuti oleh tindak tutur asertif.
\end{abstract}

Kata kunci:Tindak Tutur, Interjeksi, Panggilan, Direktif, Ajakan

\begin{abstract}
[Types of Speech Acts Following Calling Interjection In Japanese] In speaking, there are times when a calling interjection can be followed by more than one type of speech acts. This research discusses the calling interjection which are used by male speakers in the film Brother Beat. In addition, this study also discussed what kind of speech acts that may follow the call in a speech interjection. The data in this study is a narrative that contains interjection calling spoken by male speakers in the Brother Beat movie. The method used is descriptive qualitative method. To get the data, the researcher usesscrutinize technique and tapping notes method. The results obtained in this research are, calling interjection, such as Anosa, oi, Anona, nee, you, and ano, are often used by male speakers to call the addressees. After the calling interjection, directive speech act and assertive speech act are speech act which appear to follow the calling interjection. Interjection ano sa, oi, anona, and ano, are types of calling interjection which can be followed by a directive speech acts and assertive speech act. In the other hand, calling interjection of nee, can be only followed by a directive speech act, while calling interjection of you can be followed by a ssertives speech act.
\end{abstract}

Keywords:speech act, interjection, calling, directive, assertive

\section{Pendahuluan}

Dalam berkomunikasi ada kalanya penutur merasa kaget, heran, dan lega terhadap informasi yang ia terima. Untuk mengekspresikan perasaannya terhadap informasi yang telah diterima, penutur biasanya menggunakan suatu kata agar petutur mengerti apa yang dirasakan penutur

${ }^{*}$ Penulis Korespondensi.

E-mail: maharanipr_yellow@yahoo.co.id tanpa harus menjelaskan panjang lebar. Dalam ranah linguistik, kata yang bertugas mengungkapkan perasaan pembicara, dengan secara sintaktis tidakberhubungan dengan kata-katalain dalam ujaran disebut dengan interjeksi (Kridalaksana, 2009).

Interjeksi dalam bahasa Jepang disebut dengan kandoushi ( 感動 詞). Interjeksi memiliki banyak jenis, diantaranya interjeksi yang mengungkapkan perasaan, panggilan, 
jawaban, dll. Penggunaan interjeksi tentu saja dibedakan berdasarkan konteks terjadinya tuturan.Konteks diantaranya meliputi siapa peserta tutur, tempat terjadinya tuturan, tingkat keformalan, dll.

Perbedaan konteks turut memengaruhi interjeksi yang dipakai penutur dalam berkomunikasi. Pemilihaninterjeksi oleh penutur ditentukan pula oleh maksud penutur saat bertutur. Misalnya, interjeksi yangdigunakan pembicara saat memanggil seseorang dengan maksud untuk menanyakan sesuatu akan berbeda dengan interjeksi yang dipakai ketika memanggil seseorang dengan tujuan ingin meminta tolong. Suatu interjeksi pun ada kalanya digunakan untuk menyampaikan maksud yang berbeda dari penutur, seperti pada contoh penggunaan interjeksi panggilan di bawah ini:

Dialog berikut ini terjadi antara Tatsuya (laki-laki, 24 tahun) dan adiknya yang bernama Junpei (laki-laki, 20 tahun). Keduanya ada di meja makan, saat Tatsuya bertanya kepada Junpei apakah kemarin Junpei menemui seseorang

$$
\begin{aligned}
& \text { Tatsuya : :あのな, 純平 昨日誰かと } \\
& \text { 会ってたのか } \\
& \text { Ano na, Junpei kinou dareka to atteno } \\
& \text { ka? } \\
& \text { Hei, Junpei kemarin apa kamu } \\
& \text { bertemu dengan seseorang? }
\end{aligned}
$$

Junpei : 何で?

Nan de?

Mengapa?

(Brother Beat, ep. 3)

Interjeksi yang muncul dalam dialog di atas adalah ano na. Interjeksi tersebut dipakai Tatsuya untuk memulai sebuah percakapan yang tidak dibicarakan sebelumnya kepada Junpei. Dalam hal ini, Tatsuya menanyakan sesuatu hal kepada Junpei. Tuturan Tatsuya di atas termasuk ke dalam tindak tutur direktif.

Di sisi lain, interjeksi ano na tidak hanya muncul di depan tindak tutur direktif, namun juga dapat muncul mengawali tindak tutur lainnya, seperti pada contoh dialog di bawah ini:

Dialog di bawah ini terjadi antara Tatsuya, Junpei dan Harue (perempuan, 46 tahun). Harue adalah ibu dari Tatsuya dan Junpei. Dialog terjadi saat pacar Tatsuya yang bernama Chisato, memasak dan mencuci piring untuk keluarga Tatsuya. Harue dan Junpei merasa senang dengan keberadaan Chisato yang dianggap membantu pekerjaan rumah tangga. Namun Tatsuya merasa bahwa Chisato tidak seharusnya melakukan pekerjaan tersebut.

Tatsuya

$$
\begin{aligned}
& \text { : あのな, 知里は ま } \\
& \text { だ この家の客だぞ } \\
& \text { ano na, Chisato wa } \\
& \text { mada kono ie no kyaku } \\
& \text { da zo } \\
& \text { Hei, Chisato masih } \\
& \text { tamu di rumah ini lho. }
\end{aligned}
$$

Junpei dan Chisato : 「知里」?

\section{Chisato?}

(Brother Beat Episode 10)

Protes yang disampaikan Tatsuya pada tuturan di atas, ditanggapi ekspresi keheranan oleh Harue dan Tatsuya, karena akhirnya Tatsuya memanggil Chisato dengan nama belakang Chisato, bukan dengan nama keluarga. Hal tersebut membuat Harue dan Junpei kaget, karena biasanya Tatsuya memanggil Chisato dengan nama keluarga.

Interjeksi dalam dialog adalah interjeksi ano na. Interjeksi tersebut diikuti dengan tindak tutur asertif, yakni berisi pernyataan oleh Tatsuya bahwa Chisato masih sebagai tamu di rumah keluarga Tatsuya.

Dari kedua dialog di atas, dapat dipahami bahwa interjeksi ano na digunakan di depan tuturan direktif dan asertif. Berdasarkan variasi tindak tutur yang muncul setelah interjeksi ano na, maka perlu dilakukan sebuah penelitian yang meneliti 
mengenai jenis tindak tutur yang dapat mengikuti interjeksi panggilan. Dalam penelitian ini akan diteliti variasi interjeksi panggilan yang dituturkan oleh laki-laki, beserta tindak tutur yang mengikutinya.

Penelitian ini menggunakan data berupa film seri yang berjudul "Brother Beat". Film seri tersebut dipilih karena mengandung banyak interjeksi panggilan yang dituturkan oleh penutur laki-lakil. Data yang dipilih adalah data berupa tuturan dengan interjeksi panggilan, yang diikuti dengan tindak tutur di belakangnya.

Penelitian ini meneliti mengenai interjeksi panggilan apa saja yang muncul dalam film Brother Beat yang dituturkan oleh penutur laki-laki. Selain itu, diteliti pula varian interjeksi yang dapat muncul mengikuti sebuah interjeksi panggilan.

Untuk dapat meneliti beberapa masalah di atas, peneliti menggunakan beberapa jenis teori, diantaranya adalah teori mengenai pragmatik oleh Levinson (1995), teori mengenai jenis interjeksi panggilan oleh Namatame (1996), teori tindak tutur oleh oleh Austin (1962) dan Koizumi (1993), teori Model Of Speaking oleh Hymes (1974), teori wacana dialog oleh Rani (2006).

Berdasarkan pemaparan di atas, peneliti memberi judul penelitian ini dengan "Jenis Tindak Tutur Yang Mengikuti Interjeksi Panggilan Dalam Bahasa Jepang"

\section{Metode Penelitian}

Metode yang digunakan dalam penelitian ini adalah deskriptif kualitatif. Deskriptif berarti bersifat menggambarkan apa adanya (KBBI, 1995). Sedangkan Strauss dan Corbin (1998: 10) mendefinisikan penelitian kualitatif sebagai penelitian yang tidak bermuara pada hasil statistik atau angka. Dengan demikian, secara sederhana, metode penelitian deskriptif kualitatif dapat dipahami sebagai metode penelitian yang menggambarkan objek dengan apa adanya dan tidak bermuara pada hasil statistik atau angka.

Dalam prakteknya, terdapat beberapa tahap yang dilakukan dalam penelitian kualitatif. Salah satunya seperti yang diungkapkan Miles dan Huberman. Miles dan Huberman (1994: 10) menyatakan bahwa dalam penelitian kualitatif, terdapat empat tahap yang harus dilakukan, yakni pengumpulan data, reduksi data, pengidentifikasian data, dan pengambilan simpulan. Penelitian ini menggunakan modifikasi proses penelitian kualitatif berdasarkan Miles dan Huberman.

Metode dan teknik pengumpulan data yang digunakan dalam penelitian ini adalah metode simak dan teknik sadap catat. Metode simak adalah metode pengumpulan data dengan cara menyimak penggunaan bahasa (Mahsun, 2005: 92). Teknik dasar dari metode ini adalah teknik sadap. Teknik sadap dianggap sebagai teknik dasar dalam metode simak karena padahakikatnya menyimak diwujudkan dengan penyadapan. Dalam hal ini, peneliti menyadap dengan cara mencatat penggunaan bahasa seseorang atau sekelompok orang yang menjadi informan. Penyadapan fenomena penggunaan bahasa, dapat dilakukan melalui fenomena penggunaan bahasa lisan maupun tertulis.

Dalam penerapannya penulis akan menyimak dan mencatat tuturan dalam wacana dialog dari video drama. Selain itu penulis juga menggunakan teknik simak bebas libat cakap, yakni teknik yang menjadikan peneliti sebagai pengamat suatu fenomena bahasa, dalam hal ini video drama.

Langkah-langkah konkrit yang dilakukan peneliti dalam mengumpulkan data adalah sebagai berikut:

1. Menyimak drama Brother Beat

2. Mengidentifikasi tuturan yang menggunakan interjeksi panggilan dengan pembicara laki-laki.

3. Mentranskrip dan menerjemahkan tuturan yang telah teridentifikasi pada langkah sebelumnya, sehingga terkumpullah data.

Setelah data terkumpul, langkah selanjutnya adalah analisis data, yang dilakukan dengan beberapa langkah sebagai berikut:

1. Menguraikan konteks dalam data

2. Mengidentifikasi interjeksi panggilan dalam tuturan. 
3. Mengidentifikasi jenis tindak tutur yang mengikuti interjeksi panggilan.

4. Setelah 3 langkah di atas dilakukan, peneliti akan membuat tabel yang memuat interjeksi panggilan apa saja yang dituturkan oleh penutur laki-laki, tuturan yang mengikuti interjeksi panggilan tersebut, dan jenis tindak tuturnya.

5. Berdasarkan tabel tersebut akan diidentifikasi, interjeksi panggilan apa saja yang muncul dalam film Brother Beat yang memiliki varian tindak tutur.

Setelah proses analisis dilakukan, selanjutnya akan dilakukan tahap penyajian data. Data akan disajikan secara deskriptif untuk menjawab dua masalah penelitian.

\section{Hasil dan Pembahasan}

Berikut ini akan diuraikan beberapa contoh

Analisis, yang menyebutkan beberapa jenis interjeksi panggilan yang muncul dalam film Brother Beat.

\section{Data 1}

Dialog di bawah ini terjadi antara Tatsuya dan rekan kerjanya yang bernama Higashi (laki-laki, 20 tahun-an). Saat baru saja sampai di kantor, Tatsuya sambil berbisik menanyakan sesuatu kepada rekannya itu.

Tatsuya ：㐫さ 俺に電話なかっ た?

Anosa ore ni dennwa nakata?

Eh, tadi ada telepon untuk aku tidak?

Higashi : あったよ

Atta yo.

Ada kok.

(Brother Beat, ep. 1)

Dalam mengawali sebuah tuturan direktif berbentuk pertanyaan, Tatsuya menggunakan interjeksi panggilan anosa kepada rekannya. Interjeksi panggilan anosa digunakan Tatsuya untuk menanyakan sesuatu yang dianggap lumayan serius, sambil sedikit berbisik kepada temannya.
Sebenarnya Tatsuya sedang mengharap bahwa ada telepon untuknya dari seorang gadis yang ia sukai.

Data 2

Dialog di bawah ini terjadi antara Riku (lakilaki, 22 tahun) dan seorang teman perempuannya saat mereka bersama temanteman lainnya bermakud pergi ke karaoke.

Riku

: ねえ, り゙うする?
この後
Nee, dou suru no?

Koto ato.

Hey, apa yang akan kamu lakukan? Setelah ini

Teman Perempuan : どうするって?

Dou suru tte?

Maksudmu apa?

(Brother Beat, ep. 3)

Dalam dialog di atas, Riku menggunakan interjeksi panggilan nee, untuk memanggil temannya. Interjeksi panggilan nee, diikuti dengan tindak tutur direktif bentuk pertanyaan. Dalam dialog tersebut, Riku bermaksud untuk mengajak teman perempuannya untuk pergi ke suatu tempat setelah berkaraoke bersama.

\section{Data 3}

Dialog di bawah ini dituturkan oleh Riku kepada Ai (perempuan, 22 tahun) yang merupakan temannya. Dialog terjadi di dalam toko yang menjual baju pengantin. Riku memuji gaun pernikahan Ai yang akan menikah dalam waktu dekat.

Riku：よう,似合ってんじゃん,そのドレ 즈 You, ni attenjyan, sono doresu.

Hei, baju itu cocok kamu pakai.

$\mathrm{Ai}$ :陸

Riku

Riku

(Brother Beat, Ep. 5) 
Dialog di atas terjadi saat tiba-tiba Riku muncul, ketika Ai sedang mencoba baju pengantinnya. Tidak menyangka bahwa Riku akan muncul, Ai hanya bisa menyebut nama Riku saat mendengar Riku memuji gaunnya. Interjeksi panggilan di atas adalah interjeksi you. Riku menggunakan interjeksi tersebut untuk menarik perhatian Ai, bahwa Riku ada di dalam toko.

\section{Data 4}

Dialog di bawah ini terjadi antara Tatsuya dan Chisato (perempuan, 24 tahun). Tatsuya tidak tahu bahwa Riku merancang kencan ganda untuk Tatsuya, Chisato, Riku, dan Ai. Tatsuya yang merasa kesal dengan ulah Riku, bertanya kepada Chisato.

Tatsuya: あの...知ってたの? こういう こと

\section{Ano...shitteta no? Kouiu koto \\ Eh...kamu tahu? Tentang hal ini \\ Chisato : いえ 陸さんから今朝電 話があって \\ 何が何でも来るようにって \\ Ie, Riku san kara kesa denwa ga atte. Nani ga nan de mo kuru you ni tte. \\ Tidak, tadi pagi ada telepon dari Riku. Apapun yang terjadi dia memintaku datang.}

(Brother Beat, Ep. 4)

Dialog di atas terjadi saat Tatsuya bertanya kepada Chisato, apakah Chisato tahu bahwa akan ada kencan ganda. Hal tersebut dijawab oleh Chisato, bahwa Chisato juga tidak tahu kalau akan ada kencan ganda seperti ini. Untuk mengawali percakapan dengan Chisato, Tatsuya menggunakan intejeksi panggilan ano.

Berikutnya akan diuraikan beberapa contoh data yang menunjukkan bahwa suatu interjeksi panggilan dapat diikuti oleh tindak tutur yang bervariasi.
Data 5

Dialog berikut ini terjadi antara tiga partisipan, yakni Tatsuya, Sakurai Harue, dan Riku. Ketiganya adalah keluarga. Tatsuya dan Riku adalah anak dari Harue. Saat makan malam, Tatsuya dan Riku memprotes masakan Harue.

Tatsuya：1おいこれインスタントだろ? (2) そ汁ぐらい,ちゃんと作れよ

Oi, kore insutando daro. Miso shiru gurai, chanto tsukure yo.

Hei, ini instan ya? Kalau hanya miso sup, buatlah dengan baik

Riku : それに何だよこれ,焦げてるしよ Sore ni nan da yo, kogeteru sho

Terus apa ini, gosong.

Harue :(4)文句があんだったら,あんたた ちが作んなさいよ.パートで疲れ て帰ってきてんだから

Monku ga andattara antatachi ga tsukunnasai yo. Paato de tsukarete kattekitendakara

Kalau ada keluhan, kalian buat sendiri. Karena aku sudah capek pulang kerja

(Brother Beat, ep.3)

Dialog di atas diawali dengan tuturan 1 yang mengandung interjeksi panggilan oi. Tuturan 1 merupakan tuturan yang berisi tentang protes terhadap sup miso instan yang dibuat Harue. Tuturan tersebut diikuti dengan tuturan 2, yang berisi perintah bahwa kalau hanya miso sup, Harue hendaknya bisa membuat sendiri. Pada tuturan 3, riku menambahkan bahwa masakan Harue gosong. Harue yang tidak mau disalahkan memberika pembelaan terhadap dirinya dalam tuturan 4 .

Dalam dialog di atas, interjeksi panggilan muncul dalam tuturan 1, yakni oi. $O i$ pada tuturan di atas, diikuti dengan sebuah pertanyaan retoris. Walaupun berbentuk pertanyaan, namun pertanyaan retoris merupakan pertanyaan yang tidak membutuhkan jawaban, sehingga termasuk ke dalam tindak tutur asertif. 
Data 6

Tuturan di bawah ini, merupakan tuturan yang dituturkan Tatsuya kepada Riku, saat Riku memanggil Harue dengan panggilan yang kurang pantas.

Tatsuya :11おい, 母親に向かって,
クソババアやめろ
Oi, haha oya ni mukatte, kuso babaa
wa yamero
Hei, kepada ibu, jangan memanggil
nenek busuk.
Riku (2)また説教かよ...
Mata sekkyou ka yo...
Kamu ceramah lagi...

(Brother Beat, ep.3)

Tuturan di atas diawali dengan tuturan 1 yang berisi perintah Tatsuya kepada Riku bahwa kepada Ibu jangan memanggil dengan panggilan nenek busuk. Mendengar perintah kakaknya, Riku merasa berkeberatan, sehingga menuturkan tuturan 2. Interjeksi panggilan oi pada tuturan 1 diikuti dengan tindak tutur direktif dengan makna perintah. Hal tersebut ditandai dengan pemarkah ro (ろ) yang menempel pada kata yameru (やめる) yang berarti berhenti (Matsuura, 1994: 1168). Yameru ketika ditempeli pemarkah ro, maka akan menjadi yamero yang memiliki arti berhentilah.

\section{Data 7}

Dialog di bawah ini terjadi antara Tatsuya dan rekan kerjanya yang bernama Higashi (laki-laki, 20 tahun-an). Saat baru saja sampai di kantor, Tatsuya sambil berbisik menanyakan sesuatu kepada rekannya itu.

Tatsuya ：市のさ 俺に電話なかっ た?

Anosa ore ni dennwa nakata

Eh, tadi ada telepon untuk aku tidak?

Higashi : あったよ

Atta yo.

Ada kok.

(Brother Beat, ep. 1)
Tuturan di atas diawali dengan interjeksi anosa, yang dilanjutkan dengan pertanyaan Tatsuya kepada Higashi. Pada tuturan 2, merupakan tuturan Higashi yang merupakan jawaban terhadap tuturan Tatsuya pada tuturan 1. Dapat diamati pada tuturan 1 bahwa di belakang interjeksi panggilan merupakan tindak tutur direktif. Disebut tindak tutur direktif karena sejatinya sebuah pertanyaan pastinya menghendaki jawaban lawan bicara.

\section{Data 8}

Dialog di bawah ini terjadi antara Junpei dan Harue. Dialog terjadi di ruang makan, saat keduanya membahas mengenai Tatsuya, yang merupakan kakak tertua Junpei.

\section{Junpei : (1)のさ、今日大学の時の同空会 のハガキが兄貴のとこ来てて. (2) それで思ったんだけど.兄貴まだ 元カノのことが忘れられないと かじやないよね? \\ Ano sa, kyou daigaku no toki no dousoukai no hagaki ga aniki no toko kitete. Sore de omottandakedo. Aniki mada moto kano no kotowa wasurerarenai to ka jyanai yo ne? Eh, hari ini kakak mendapat kartu pos reuni kampus. Dia memikirkan hal itu. Kakak tidak bisa melupakan mantan pacarnya ya?}

Harue : (3もう 2 年もたつのよ

Mou ni nen mo tatsu no yo.

Sudah tahun berlalu lho.

(Brother Beat, ep. 4)

Wacana dialog di atas diawali dengan tuturan 1 yang berisi pemberitahuan dari Junpei bahwa kakaknya telah menerima kartu pos untuk acara reuni kampus. Hal tersebut membuat Tatsuya mengingat kembali mantan pacarnya. Mendengar hal tersebut Harue merasa heran, bahwa sudah 2 tahun yang lalu Tatsuya putus dari mantan pacarnya, namun mengapa Tatsuya masih belum bisa melupakan mantan pacarnya. 
Izumi, Volume 4, No 2, 2015

p-ISSN: 2338-249X

Tersedia online di http://ejournal.undip.ac.id/index.php/izumi

Interjeksi panggilan pada dialog di atas adalah interjeksi anosa. Di belakang interjeksi tersebut diikuti sebuah pernyataan bahwa Tatsuya belum bisa melupakan mantan pacarnya. Tuturan di belakang interjeksi anosa merupakan tindak tutur asertif, karena berisi pernyataan Junpei mengenai suatu hal.

Berdasarkan hasil penelitian yang telah dilakukan , didapatkan 26 tuturan yang mengandung interjeksi panggilan dengan penutur laki-laki. Berdasarkan data, interjeksi panggilan yang muncul adalah anosa (あの さ)、oi (おい), anona (あのな), ne (ねえ), ano (あの)、 dan you (よう). Dari keenam interjeksi tersebut interjeksi oi adalah interjeksi yang paling sering muncul atau digunakan oleh pembicara,. Interjeksi oi muncul 14 kali dalam data. Sedangkan interjeksi anona dan you merupakan interjeksi yang paling jarang muncul. Keduanya muncul masing-masing 2 kali dalam data.

Berdasarkan jenis tindak tutur yang muncul, interjeksi panggilan dalam film Brother Beat mengawali tuturan direktif dan asertif. Dalam hal ini 19 data dalam penelitian adalah tindak tutur direktif yang kemunculannya diawali oleh interjeksi yobikake. Di sisi lain, muncul pula tindak tutur asertif yang mengikuti interjeksi panggilan dengan frekuensi kemunculan 7 kali dalam data. Secara ringkas, uraian di atas dapat dipahami melalui tabel berikut:

\section{TABEL INTERJEKSI PANGGILAN OLEH PENUTUR LAKI-LAKI DALAM FILM BROTHER BEAT}

\begin{tabular}{|c|c|c|c|}
\hline No. & Interjeksi. & Tuturan. & Tindak Tutur \\
\hline $1 . .1$ & あのさ & 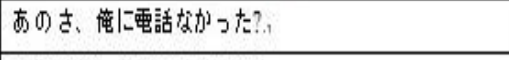 & Direktif . \\
\hline 2.1 & 掉い & おい：これインス多ントたる。 & Asertif. \\
\hline $3 . .1$ & おい: & 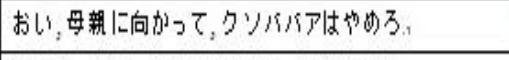 & Direktif. \\
\hline $4 \ldots$ & あのた & あのな純平昨日，誰加と会ってたのか？。 & Direktif. \\
\hline 5.1 & 捕い, & おい とういうことないたよ?。 & Direktif. \\
\hline $6 . .1$ & 极㐬 & 极え とううするここの後 & Direktif. \\
\hline 7.1 & 就菲 & 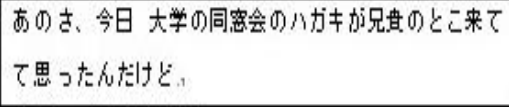 & Asertif. \\
\hline 8.1 & 极充。 & 极充、一绪汇带万う。。 & Direktif . \\
\hline $9 . .1$ & おい, & おい,そろそろ畭杯するぞ & Direktif. \\
\hline 10... & あの & あのい知ってたの？こういうこと & direktif. \\
\hline 11... & おい. & おい、兄典 早〈来いよ， & Direktif. \\
\hline $12 . .1$ & 抒い & おい、兄典知里古わん見合いするってよ、 & Asertif , \\
\hline $13 . .1$ & おい: & 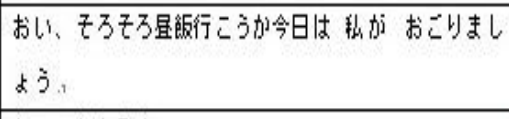 & Direktif , \\
\hline $14 . .1$ & おい, & おい わらら & Direktif : \\
\hline 15 & 52. & 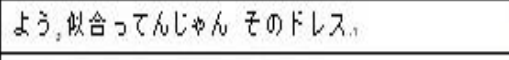 & Asertif. \\
\hline 16... & おい, & 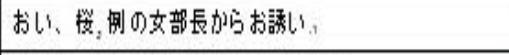 & Asertif : \\
\hline $17 . .1$ & あのさ & あのさ 相手の人ってとんな人なの？ & Direktif . \\
\hline $18 .$. & $\hbar の$ & 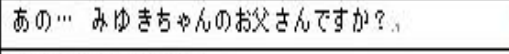 & Direktif . \\
\hline $19 .$. & おい: & おい 句してんたよ?， & Direktif . \\
\hline $20 . .1$ & $\bar{d}$ & あの、話かしたいんだ & Asertif : \\
\hline $21 .$. & おい: & おい，何恀ってんだ?， & Direktif . \\
\hline 22... & おい: & おい、挼井とこ行った?。 & Direktif . \\
\hline $23 .$. & おい & おい、会满始まるぞ、, & Direktif . \\
\hline $24 .$. & 京の放 & あのな，㚘里はまたここの家の囬たで。 & Asertif , \\
\hline $25 . .1$ & 极充. & 极えこのクラス板加とう? 。 & Direktif : \\
\hline
\end{tabular}




\section{Simpulan}

Berdasarkan penelitian yang telah dilakukan, maka dapat disimpulkan bahwa:

1. Interjeksi panggilan yang muncul dalam film Brother Beat oleh penutur laki-laki ada 6 jenis, yakni: anosa (あのさ) dengan tiga kali kemunculan、oi (おい), dengan 13 kali kemunculan, anona (あの な) dengan dua kali kemunculan, ne (ね え) dengan tiga kali kemunculan, ano (あ の) dengan tiga kali kemunculan、 dan you (よう) dengan satu kali kemunculan.

2. Tindak tutur yang mengikuti interjeksi panggilan dalam film Brother Beat adalah tindak tutur direktif dan tindak tutur asertif. Tindak tutur direktif adalah tindak tutur yang paling sering muncul. Hal tersebut dikarenakan, penutur laki-laki pada film kebanyakan bermakud memanggil lawan tuturnya dengan tujuan memberikan perintah. Interjeksi anosa, oi, anona, dan ano muncul mengawali tindak tutur direktif dan asertif. Namun dalam film, interjeksi nee, hanya muncul mengawali tuturan direktif saja, sedangkan interjeksi you muncul mengawali tuturan asertif saja.

\section{DAFTAR PUSTAKA}

Austin, John Langsaw. 1962. How to Do Things with Words. Great Britain: OxfordUniversity Press.

Departemen Pendidikan Nasional. 1995. Kamus Besar Bahasa Indonesia. Jakarta: Balai Pustaka

Hymes, Dell. 1974.Foundations of Sociolinguistics: An Ethnographic Approach. Philadelphia: U of Pennsylvania $\mathrm{P}$

Koizumi, Tamotsu. 1993. Gengo Nyuumon. Tokyo: Taishukan Shoten

Kridalaksana, Harimurti. 2009. Kamus Linguistik. Jakarta: Gramedia Pustaka Utama

Levinson, Stephen $\quad$ C. 1995. Pragmatics.Melbourne: The Press Syndicate of The University of Cambirdge.

Mahsun. 2005. Metode Penelitian Bahasa. Jakarta: PT Raja Grafindo Persada

Miles, M.B. \&Huberman, A.M. (1994). Qualitative data analysis: An expanded sourcebook. New York: SAGE Publications.

Namatame, $\quad$ Yasu. 1996. GendaiNihongoBunten. Japan: Nihongo No Bonjinsha

Rani, Abdul dkk. 2000. Prinsip-prinsip Analisis Wacana.Jakarta: Departemen Pendidikan Nasional.

Straus, Anselm dan Juliet Corbin. 1998. Basics of qualitative research. California: Sage 